\title{
THE AMERICAN DARK AGES
}

\author{
Onur Hayırlı ${ }^{*}$, Dilek İşler ${ }^{2}$ \\ ${ }^{1}$ Mr., TURKEY, ohayirli@yahoo.com \\ 2 Ms., TURKEY, dileksler@yahoo.com \\ ${ }^{*}$ Corresponding author
}

\begin{abstract}
This article historically will review some cases for lynch culture which is again blacks in America. And will examine the term 'Afro-American'. Cases like 'Michael Brown', 'Eric Garner' and 'Antonio Martin' are proof of violence is still going on again black society.

Lynching is a part of America's dark sides. Behind lynching, it lays a brutal history of domestic violence. For years, maybe for centuries, American people have lynched Black people because of various accusations. These lynching were, in general, racially motivated. Anti-Black violence roughly began in 1880s. Between 1880 s and 1950s, there were lynching and anti-lynching riots. Rayford W. Logan, who was an African American historian and Pan-African activist, called this era as American Dark Ages. (Yale.edu) by changing its form, lynching is still going on.

It is the act of killing people for any alleged crime, without trial, jury, judge, appeal. It began after Civil War. During Reconstruction, freedmen tried to use their newly-given rights. Abraham Lincoln abolished the slavery with the Thirteenth Amendment in 1865. The Fourteenth Amendment gave citizenship to Blacks in 1868. The Fifteenth Amendment prohibited discrimination in voting rights in 1870. However, white people applied several ways to deter black men from voting and living freely. Disenfranchisement, Jim Crow Laws and Lynching came out and lasted for years. It is true. Lynching based on racial segregation and prejudice continues in a different form. Unfortunately, it has a long history. Jesse Washington, Emmett Till, Laura and L.D Nelson, Michael Brown, Eric Garner were killed as a result of almost same perspective, same prejudice and brutality. First of all, it is crucial to know black history.
\end{abstract}

As a result, the lynching problem does not depend on the state. In every state, people have lynched, hanged, killed or shot. American society has been prone to brutality toward black people as it is understood from the examples. If precautions are not taken or the widespread view is not changed, these cases are going to destroy the 'freedom and democracy'.

Note: The term 'The American Dark Ages' was coined by historian Rayford W. Logan.

Keywords: African Americans, Human Rights, USA, America, Racism, Lynch Culture

\section{METHOD, SUBJECT, PURPOSE, SIGNIFICANCE}

This article is interpretive, qualitative and will be example of case study according to human rights perspective. This article will explain lynch culture according to recent black cases in the light of black history. Main purpose of this article is to compare Michael Brown, Eric Garner, Antonio Martin cases and attract attention to human rights in the USA society. In discussion part; all those cases also show that lynch culture 
still goes on in spite of all struggles of black leaders like Martin Luther King Jr. or Malcolm X. This is ongoing and covered problem for society that's why it is significant.

\subsection{Lynch Culture}

In her famous poem, Gwendolyn Brooks summarizes Blacks' situation dramatically. She writes;

The fun was disturbed, then all but nullified

When the Dark Villain was a blackish child

Of fourteen, with eyes still too young to be dirty,

And a mouth too young to have lost every reminder

Of its infant softness.

(The poem 'A Bronzeville Mother Loiters in Mississippi. Meanwhile, a Mississippi Mother Burns Bacon' concerns the murder of Emmett Louis Till, a fourteen-year old boy who was murdered in Mississippi on August 28, 1955.)

Emmett Till, like many other black people, was murdered in, because he had 'wolf-whistled' at a white woman (FBI news stories, 2014). The case happened in 1955. Currently, Michael Brown and Antonio Martin were shot and Eric Garner passed away after chokehold by police. These happened in 2014. It seems as if a long time had passed since Reconstruction and Civil Rights Movement (1954-68). However, not a lot of things have changed throughout time.

As Toni Morrison said: 'Racism is a social construct. There is no such thing as race, none. There is human race in biological anthropology and biology. However in culture, not. It is created because it has some functions.' As she expressed, the concept of race was created to justify slavery, to make it possible to earn money, to give some part of society priority. Although it seems on the surface that people have come over the issue, little has changed for a long time. People are becoming more and more racist. Movies, media, point of views etc. support the issue. The fact of racism is confronted in many spheres. First of all, In Oscar Awards, for instance. Since the foundation of Oscar awards, 2437 people have been given awards just 31 of whom have been black people. Secondly, there are some social and cultural myths about black people like 'black rapist' or 'black criminal' which criminalize the people. Thirdly, people tend to change their outlooks with surgery because of cultural racism as in the case of Michael Jackson. Finally, the racism can be seen in the Hollywood movies where blacks play inferior roles or are shown as clumsy and 'funny' people. Many more examples can be listed. However, the worst of all comes with the police violence against black people. It used to show itself in the form of lynching which has been replaced by police violence.

Lynching is a part of America's dark sides. Behind lynching, it lays a brutal history of domestic violence. For years, maybe for centuries, American people have lynched Black people because of various accusations. These lynching were, in general, racially motivated. Anti-Black violence roughly began in $1880 \mathrm{~s}$. Between 1880 s and 1950s, there were lynching and anti-lynching riots. Rayford W. Logan, who was an African American historian and Pan-African activist, called this era as American Dark Ages. (Yale edu.) By changing its form, lynching is still going on.

Lynching is defined in the Oxford Dictionaries as the following:

'(Of a group of people) kill (someone) for an alleged offence without a legal trial, especially by hanging.'

It is the act of killing people for any alleged crime, without trial, jury, judge, appeal. It began after Civil War. During Reconstruction, freedmen tried to use their newly-given rights. Abraham Lincoln abolished the slavery with the Thirteenth Amendment in 1865. The Fourteenth Amendment gave citizenship to Blacks in 1868. The Fifteenth Amendment prohibited discrimination in voting rights in 1870 . However, white people applied several ways to deter black men from voting and living freely. Disenfranchisement, Jim Crow Laws and Lynching came out and lasted for years.

First of all, Southern states passed laws, known as disfranchisement, to deter black men from voting. Poll taxes, Literacy Tests, Grandfather Clauses made it difficult for black people to vote. They faced high taxes, intimidation and violence when they attempted to use their right to vote. Secondly, after Reconstruction, Jim Crow Laws dominated the atmosphere. These laws were based on 'separate but equal'. The laws gave black men inferior positions and situations compared to white men, helped de jure segregation to continue and increase. Thirdly, black men faced with lynching which is the cruel combination of racism and prejudice. Lynching came in the form of hanging, castrating and even burning black people alive. 
According to studies of the latest data compiled by the Federal Bureau of Investigation; 'About twice a week, or every three or four days, an African American has been killed by a white police officer in the seven years ending in 2012.' (Guardian)

It is true. Lynching based on racial segregation and prejudice continues in a different form. Unfortunately, it has a long history. Jesse Washington, Emmett Till, Laura and L.D Nelson, Michael Brown, Eric Garner were killed as a result of almost same perspective, same prejudice and brutality. First of all, it is crucial to know black history.

\section{CIVIL WAR, RECONSTRUCTION AND KKK}

Being brought from Africa by merchants which is known as Atlantic Slave Trade, African American people suffered a lot. They were made slaves, made to work for white people. In the South, the climate was suited for the cultivation of the cotton. South was mainly producing cotton. By $1830 \mathrm{~s}$, cotton fields expanded from the Atlantic seaboard to central Texas. In 1860, production increased from 300.000 bales to 5 million. (Lauter, 2006; 395) Cotton Gin invented by Eli Whitney in 1794 played an important role. In that way, south became 'cotton kingdom' which was also a slave empire. There were 2 million slaves in 1830. Between 1861 and 1865, American Civil War continued at the end of which slavery was abolished by President Abraham Lincoln. Black people were given citizenship and right to vote. Afraid that South culture would be changed as a result of freedom, white southerners started to react in multiple ways. Black Codes were common after the war. Some states passed Jim Crow Laws to restrict blacks from freedom and force them either to work in the plantations again or to stay out of whites' place. In 1866, Confederate veterans founded Ku Klux Klan. (Lauter, 2006; 516) In the beginning, it was founded for fun, fellowship and being together. However, it grew gradually. It led several lynching and murder toward blacks.

National Association for the Advancement of Colored People (NAACP) was founded in 1909. Its founders, W.E.B. DuBois and Booker T. Washington, did a lot of thing to improve blacks' condition and situation in the country. The winds of change began to blow across America in 1954 when Brown vs. Board of Education overturned Plessy vs. Ferguson decision of 1896. Court decided that separating schools is unconstitutional. Another hopeful case happened at the time when Rosa Parks, 42 years old black woman, refused to give her seat in the bus to a white man. Martin Luther King, Jr. took her cause up and led a bus boycott in Montgomery, Alabama. The glory was the passage of Civil Rights Act of 1968. (Black History).

\section{CRIMES OF HATRED AND PREJUDICE}

Although there were hate crimes, this word did not enter the nation's vocabulary till 1980s when hate groups like Skinheads started to emerge...

There are several black people lynched and killed to be remembered and referred. However, some of them will be enough to show the prejudice, racism and hatred. In 1893, Henry Smith was tortured and murdered in Paris, Texas. The white people murdered him claiming that he had killed a three-year old child of a policeman. Laura and L.D Nelson was lynched on May 25, 1911, near Okemah, Oklahoma. The police officers came Laura and her husband's home to investigate a theft of a cow. Their son shot the police. Laura and her son were taken to the prison in the town. At night, they were kidnapped from the prison by a group of men. Some resources claim that Charley Guthrie, the father of folk singer Woody Guthrie, was also among them. Laura and her son were killed by hanging. Rightfully, Mark Twain called America as The United States of Lyncherdom. (In 1909, he wrote an essay named The United States of Lyncherdom as a reaction to a newspaper article supporting lynching. Virginia edu.) The Nelsons are among thousands of people killed in America. Between the years 1882 and 1968, according to the numbers of Tuskegee Institute, 4,743 people were lynched in the United States, 3,446 were black and 1,297 were white. 73 percent of them was in the South.

The lynching went on 1950s and 1960s. In 1957, Willie Edwards, husband and a father, was murdered by members of Alabama Ku Klux Klan. Then in 1959, Mack Charles Parker was accused of raping a pregnant woman. Three days before he was to stand trial, he was kidnapped from his cell and shot in Mississippi. Nobody was indicted for the killing. James Earl Chaney, Andrew Goodman and Michael Schwener were shot at a close range. Andrew and Schwener were white but Mississippi White Knights of the Ku Klux Klan killed them because they were activists in the Civil Rights Movement. When it comes to 1980s, Michael Donald was murdered by Ku Klux Klan members in Alabama in 1981. Jonny Gammage who was a black motorist was killed in Allegheny County, Pennsylvania on October 12, 1995. He was stopped on the road and after a small fight with the officers, he was suffocated because of the pressure made on his neck 
according to the autopsy reports. In 2008, Philadelphia police officers were videotaped while beating three black men. They were sued by the black men but they acquitted.

It may seem that these killings are not same with lynching. However, the reason is all same. People used to hang, castrate and kill blacks because they were prejudiced, racist and did not want black people be equal with them. After 1970s, lynching changed form. People did not hang or castrate blacks, but oppression and violence continued in the forms of beating, kidnapping and torturing. It also took the form of police brutality. Policemen did not abstain from killing black teenage boys.

\subsection{Michael Brown, Eric Garner, Antonio Martin}

In spite of all the advancements in the technology, space, science or medicine, humanity have not improved and widened its mind. The killings are still around. Eric Garner passed away in New York on July 17, 2014. Protests followed his death. Many people among whom are the poet Daniel J. Watts protested the event. Police officers were suspicious that he was selling illegal cigarettes. While trying to arrest him, the police officer Daniel Pontaleo caused his death. Many describes Garner's death as chokehold. On December 3, 2014, the court decided that Pontaleo was not guilty. Protests occurred in Chicago, Washington, Atlanta and Minneapolis in which more than 300 people were arrested.

On August 9, 2014, in Ferguson Missouri, Michael Brown, 18 year-old black boy, was shot by the police officer Darren Wilson. This time, police use of force doctrine was began to be questioned nationwide. Barack Obama announced that the government would spend US\$75 for body cameras. Darren Wilson resigned from his job concerning security reasons. Currently, Roger Goldman, a Saint Louis University law professor and Senator Jamilah Nasheed are seeking to update the Missouri state law.

Antonio Martin was shot by a police officer on December 22, 2014. It is claimed that he pointed a gun to the police officer. Police showed a video cut to the public. However, nothing was clear in the video that government released. The very words of Toni Martin who is Antonio Martin's mother summarize the whole case:

'Give me ma baby.'

He was young and with his girlfriend when he was shot.

There is also another issue to be discussed. The lynching does not depend on the state.

Rumain Brisbon, unarmed father of four was shot by the police because police mistook his bottle of pills for a gun. The case took place in Phoenix, Arizona in 2014. The family is still waiting for the court decision. Tamir Rice was shot and killed by police officer in Cleveland, Ohio. Unfortunately, the list can go forever because the violence does not stop and continues with accelerating rates.

In every state, people have been lynched, hanged, killed or shot. American society has been prone to brutality toward black people as it is understood from the examples. People do not discuss the race issue anymore. They prefer to keep it under the carpet and pretend as if there was not an issue like this. Even if they do not discuss it, the protests that have been occurring for years show the aggression and anger of black people on the face of the violence.

Rosa Parks started all these struggle when she refused to give her seat to a white man on December 1st, 1955. There were of course many other cases that NAACP (National Association for the Advancement of Coloured People) supported before. However, Montgomery Bus Boycott, started on December 1st, 1955 and continued till December 26th, 1956, was a seminal event happened against racial segregation and spurred the Civil Rights Movement. Afterwards, Civil Rights Movement of 1960s started slowly. From 1954 till 1964, black people tried to change the situation with boycotts, campaigns of civil resistance, sit ins, marches and sometimes violent confrontations. Montgomery Bus Boycott (1955-1956), Greensboro Sit-ins (1960) and the Selma to Montgomery Marches (1965) are some examples of the actions. 'I Have a Dream' speech of Martin Luther King, Jr. was famous for inspiring thousands of blacks in The March on Washington for Jobs and Freedom at the National Mall in 1963. Civil Rights Act came in 1964 and banned the discrimination based on 'race, colour, religion, or national origin'.

\section{DISCUSSION}

After World War I, a new term, 'New Negro', was introduced. It described the new spirit of militancy and impatience of the post-war. When black veterans came back home after WWI, they found the situation as bad as battlefield. Many of them were attacked just because they were wearing uniforms. A. Philip Randolph 
introduced the term in 1917 and supporters of New Negro movements claimed that black should fight back when whites attack them.

A very recent protest is still going on Baltimore, Maryland. The unrest had been going on since the deaths of Eric Garner in New York, Michael Brown in Ferguson Missouri and Walter Scott in North Charleston, South Carolina. However, the latest eruption came after days of protests over Freddie Gray, who passed away on April 19, after Baltimore police arrested him. 25-year-old Freddie got a fatal spinal injury during the police custody and passed away aftermath.

All these are the result of years and decades of mistrust, of misfortune, of despair that it is just coming out in anger. The black people are fed up with the mainstream culture, discriminative point of views. If precautions are not taken or the widespread view is not changed, these cases are going to destroy the 'freedom and democracy'.

\section{REFERENCE LIST}

And Justice for All1954-1971. Web. 22 Dec 2014. < www.fbi.gov/about-us/history/a-centennialhistory/and_justice_for_all_1954-1971 >

Civil Rights Movement. Web. 22 Dec 2014. < http://www.history.com/topics/black-history/civil-rightsmovement >

Gibson, Robert A. (2014). The Negro Holocaust: Lynching and Race Riots in the United States, 1880-1950. Web. 22 Dec 2014. < www.yale.edu/ynhti/curriculum/units/1979/2/79.02.04.x.html >

FBI news stories. (2014). Hate Crimes Add an Element of Bias to Traditional Crimes-and the Mixture is Toxic to Our Communities. Web. 22 Dec $2014 .<$ www.fbi.gov/aboutus/investigate/civilrights/hate_crimes

Lauter, Paul, Richard Yarborough, John Alberti. (2006). The Health Anthology of American Literature: Volume E. 7th Edition. 2006. Print.

The Long Arm of the Law, Reopened Investigation into the 1955 Kidnapping and Murder of Emmett Till. Web. 22 Dec 2014. < www.fbi.gov/news/stories/2004/june/till060104 >

Twain, Mark. (2014). The United States of Lyncherdom. Web. 22 Dec 2014. <people.virginia.edu/ sfr/enam482e/lyncherdom.html >

Wilkerson, Isabel. (2014) Mike Brown's shooting and Jim Crow lynchings have too much in common. It's time for America to own up. Web. 22 Dec 2014. < www.theguardian.com/commentisfree/2014/aug/25/mikebrown-shooting-jim-crow-lynchings-in-common > 